\title{
ANALISIS KINERJA SAHAM LQ45 SEBELUM DAN SELAMA PANDEMI CORONAVIRUS DISEASE (COVID-19) DI INDONESIA
}

\author{
Mulyadi, Noorchamid Ustadi, Dheo Rimbano, Martini, Henry Anggoro Djohan \\ mulyadi@ univbinainsan.ac.id, \\ E-mail : ${ }^{1}$ Universitas Bina Insan, ${ }^{2}$ Akademi Entrepreneurship Terang Bangsa
}

\begin{abstract}
This study analyzes the performance of LQ45 shares before and during the Covid-19 pandemic in Indonesia. This study uses the monthly LQ45 stock price on the Indonesia Stock Exchange. The analysis uses two different conditions, before and during Covid-19 pandemic condition in Indonesia to see differences in conditions with a quantitative approach by emphasizing hypothesis testing. This research uses comparative causal research techniques. The results explained there were significant differences in the performance of LQ45 shares before and during the Covid-19 Pandemic in companies listed on the Indonesia Stock Exchange. The t-value from the results of the data processing analysis is 3.009 with sig. 0.004 , it can be concluded that $H_{(a)}$ is accepted and $H_{(0)}$ is rejected. The performance of LQ45 shares on the Indonesian stock exchange experienced a decline during the pandemic that occurred in Indonesia. This situation caused many companies to suffer losses.
\end{abstract}

Keywords : LQ45 Stocks, Indonesia Stock Exchange, The Covid-19 Pandemic

\begin{abstract}
ABSTRAK
Penelitian ini menganalisis kinerja saham LQ45 pada saat sebelum dan selama pandemic covid-19 di Indonesia. Penelitian ini menggunakan harga saham LQ45 bulanan di Bursa Efek Indonesia. Analisis menggunakan dua kondisi yang berbeda, yaitu sebelum pandemic dan selama pandemic covid-19 di Indonesia untuk melihat perbedaan kondisi dengan pendekatan kuantitatif dengan menekankan pada pengujian hipotesis. penelitian ini menggunakan teknik penelitian kausal komparatif. Hasil penelitian menunjukkan bahwa terdapat perbedaan kinerja saham LQ45 yang signifikan sebelum dan selama Pandemi covid-19 pada perusahaan yang terdaftar di Bursa Efek Indonesia. Nilai t hitung dari hasil analisis olah data adalah sebesar 3,009 dengan sig 0.004, maka dapat disimpulkan bahwa $\mathrm{H}_{\mathrm{a}}$ diterima dan $\mathrm{H}_{\mathrm{o}}$ ditolak. Kinerja saham LQ45 pada bursa saham Indonesia mengalami penurunan selama masa pandemic yang terjadi di Indonesia. Situasi ini menyebabkan banyak perusahaan mengalami kerugian.
\end{abstract}

Keywords : Saham LQ45, Bursa Efek Indonesia, Pandemi Covid-19 
I. PENDAHULUAN

Coronavirus disease (covid-19) merupakan penyakit yang sedang mewabah hampir keseluruh dunia. Hanya dalam waktu singkat, penyebaran virus ini terus meningkat bahkan juga menambah angka kematian dengan cepat. Penyebaran yang sangat cepat dan susah dikendalikan ini dinyatakan sebagai pandemik dan diperlukannya langkah strategis untuk menanggulanginya.

Kejadian ini bermula pada akhir tahun 2019 dengan diberitakan adanya new emerging infectious disease di Kota Wuhan Provinsi Hubei, China yang disebabkan oleh Coronavirus Disease (Covid-19) [1]. Hal ini mengingatkan pada kejadian 17 tahun yang lalu, di mana wabah Severe Acute Respiratory Syndrome (SARS) muncul pertama kali di China. Jika dilihat dari tingkat kematian akibat virus tersebut (Case Fatality Rate atau CFR), CFR Covid-19 lebih rendah dibandingkan dengan CFR SARS, yaitu sebesar $2 \%$ sedangkan SARS mencapai $10 \%$. Walaupun CFR lebih rendah tetapi kasus Covid-19 berkembang dengan cepat dan telah menyebar lebih dari 200 negara di dunia [2]

Coronavirus adalah virus yang menyebabkan flu biasa hingga penyakit yang lebih parah seperti sindrom pernapasan timur tengah (MERS-CoV) dan Sindrom penafasan akut parah (SARS-CoV) virus ini berawal dari kota Wuhan Negara China yang akhirnya menyebar ke Negara lain (WHO, 2019). Penyebaran virus corona, pemerintah di seluruh dunia sedang berjuang untuk menemukan cara untuk mencegah penyebaran virus corona. Beberapa negara melarang pengunjung dari luar negeri bahkan luar kota untuk berkunjung, juga diharuskan dikarantina mandiri selama 14 hari sebelum memasuki Negara/kota asalnya. Namun, situasinya semakin di luar kendali dan risiko pandemi di seluruh dunia meningkat, masalah ini dapat meningkatkan kesulitan bagi seluruh dunia dalam mengurangi penyebaran coronavirus.

Penyebaran virus yang sangat cepat ini telah berpengaruh besar terhadap perekonomian dunia. Sebelum coronavirus menyebar, beberapa lembaga internasional memprediksi laju ekonomi dunia melemah karena beberapa faktor global, seperti perang dagang, geopolitik, dan lainnya. Kehadiran coronavirus sekarang ini dianggap sebagai dampak tambahan yang akan melemahkan pertumbuhan ekonomi dunia [3]. Sejak penyebaran coronavirus disebut sebagai kejadian pandemik, telah menambah perekonomian dunia menjadi semakin melemah termasuk Negara Indonesia. Hal ini dikarenakan terjadi kelemahan ekonomi secara global yang berdampak secara langsung pada ekonomi Indonesia. Selain itu, banyak Negara yang melakukan lockdown untuk mencegah terjadinya penularan virus tersebut hingga meluas ke berbagai Negara. Pandemik ini telah membuat ketidakstabilan ekonomi Indonesia. Salah satunya yang menjadi perhatian adalah tingkat perdagangan dan investasi di Indonesia.

Penyebaran covid 19 dan kebijakan yang di ambil pemerintah sebagai upaya pencegahan corona virus telah berdampak pada iklim investasi Indonesia. Seperti terlihat pada gambar berikut: 


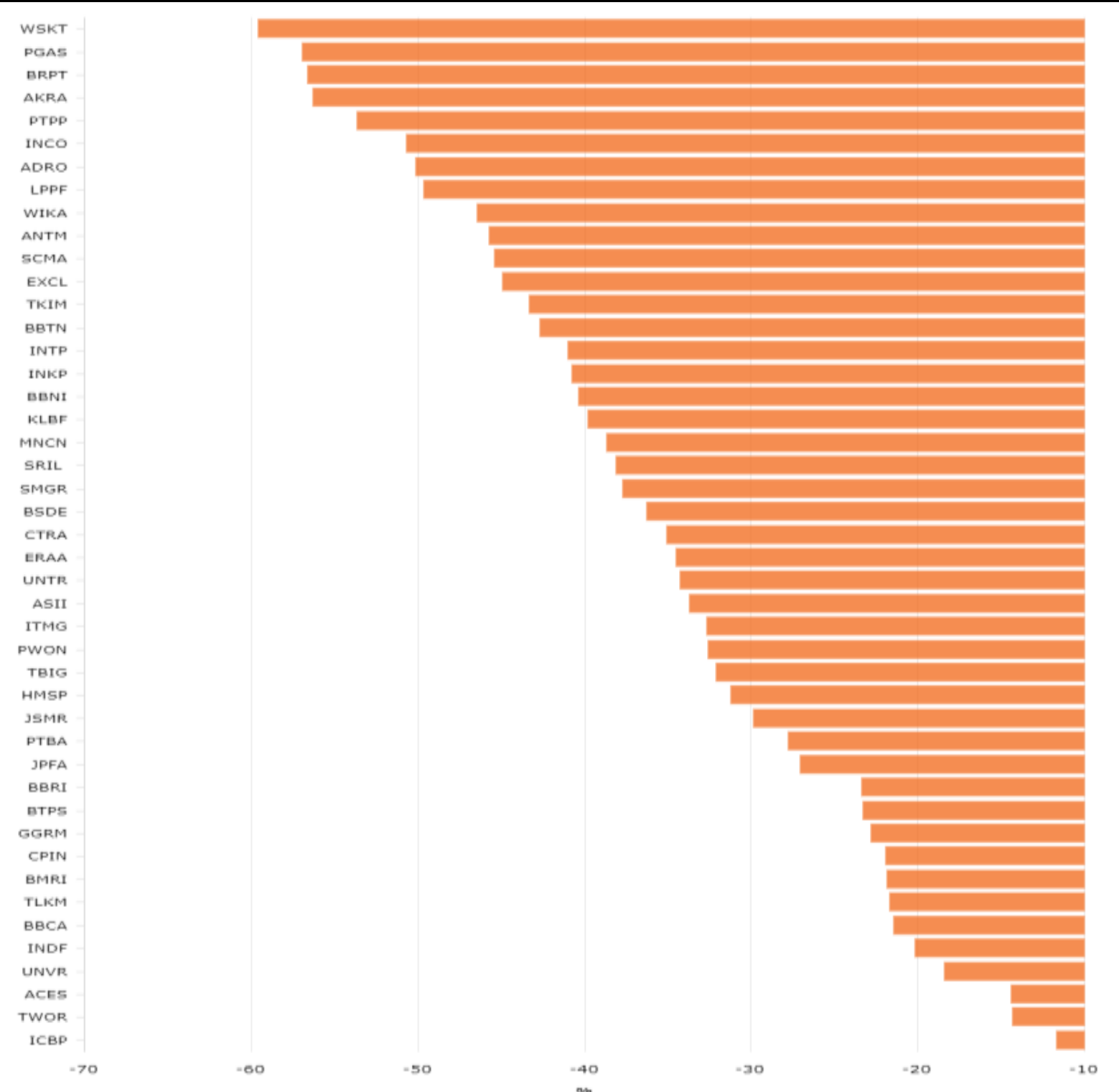

Sumber : R. Analytics, 2020

Gambar 1

Kinerja Saham LQ45 (2 Januari-12 Maret 2020)

Berdasarkan gambar 1.1 terlihat bahwa Kinerja pasar saham merosot seiring kekhawatiran investor di tengah perlambatan ekonomi dan wabah virus corona. Di Bursa Efek Indonesia (BEI), indeks harga saham gabungan (IHSG) tercatat turun $22 \%$ sejak awal tahun. Penurunan kinerja IHSG berdampak pula terhadap saham-saham berkapitalisasi besar yang tergabung dalam LQ45. Seluruh saham di indeks LQ45 ini telah mengalami penurunan. Tercatat penurunan harga saham terbesar terjadi pada saham Waskita Karya (WSKT) yang turun hingga
59,6\% sejak awal tahun. Sementara saham Indofood CBP Sukses yang mengalami penurunan terendah sebesar $11,66 \%$ [4].

Berdasarkan pada data tersebut, coronavirus telah memberikan dampak menurunkan kinerja indeks saham LQ45. Indeks saham LQ45 merupakan saham unggulan yang yang ada di Indonesia. Indeks LQ45 terdiri dari 45 emiten dengan likuiditas (LiQuid) tinggi, yang diseleksi melalui beberapa kriteria pemilihan. Selain penilaian atas likuiditas, seleksi atas emiten-emiten 
tersebut juga mempertimbangan kapitalisasi pasar [5].

Indeks saham LQ45 juga memiliki jaminan sebagai produk investasi yang banyak diminati investor (Idx stock index handbook v1.0, 2019). Selain itu, risiko saham LQ45 memiliki nilai yg lebih rendah dibandingkan non-LQ45 [6].

Berdasarkan analisis tersebut, peneliti tertarik untuk melakukan analisis kinerja saham LQ45 selama masa pandemic Covid 19 ini untuk melihat adakah pengaruh yang signifikan terhadap pandemik ini terhadap indeks saham LQ45.

Penelitian berkaitan dengan pandemic Corona Virus di Indonesia masih sangat jarang karena kondisi ini masih tergolong baru terjadi di dunia dan Indonesia. Penelitian ini hanya menghubungkan variebel indeks saham LQ45 sebelum dan sesudah pandemic Covid-19 dan belum pernah dilakukan penelitian terkait dengan kinerja saham pada kondisi pandemi ini.

Penelitian sebelumnya yang berkaitan seperti yang dilakukan oleh Soureka \& Muchlis, 2007 dan Ayu et al., 2013 yang menganalisis saham dalam kondisi yang berbeda (sebelum dan setelah stock split). Hasil penelitian menunjukkan terdapat perbedaan kinerja saham dengan kondisi yang berbeda dan menjadi lebih baik setelah stock split [7]; [8]. Kondisi ini menjadi pertimbangan untuk dilakukan penelitian tentang kondisi yang terjadi sekarang pada kinerja saham melihat kondisi pandemi telah banyak memberikan pengaruh bagi semua elemen kehidupan masyarakat. Penelitian sebelumnya yang dilakukan oleh Khan et al., 2020; Budiyanti,
2020; Evans, 2020 menggambarkan efek negatif dari penyebaran covid-19 yang merugikan berbagai pihak [9];[10];[11]. Kondisi ini perlu adanya bukti empiris atas kinerja saham yang ada untuk melihat pengaruhnya pada masa pandemi.

\section{TINJAUAN PUSTAKA}

Saham Indeks LQ45 dipilih dari saham dengan kapitalisasi pasar yang besar dan likuiditas yang tinggi dengan kriteria pemilihan yang ketat. Sejak diluncurkan pada bulan Februari 1997 ukuran utama likuiditas transaksi adalah nilai transaksi di pasar reguler. Sesuai dengan perkembangan pasar dan untuk lebih mempertajam kriteria likuiditas, maka sejak review bulan Januari 2005, jumlah hari perdagangan dan frekuensi transaksi dimasukkan sebagai ukuran likuiditas. Sehingga kriteria suatu emiten untuk dapat masuk dalam perhitungan indeks LQ45 adalah mempertimbangkan faktor-faktor sebagai berikut [5]:

1. Telah tercatat di BEI minimal 3 bulan.

2. Aktivitas transaksi di pasar reguler yaitu nilai, volume dan frekuensi transaksi.

3. Jumlah hari perdagangan di pasar reguler

4. Kapitalisasi pasar pada periode waktu tertentu.

5. Selain mempertimbangkan kriteria likuiditas dan kapitalisasi pasar tersebut di atas, akan dilihat juga keadaan keuangan dan prospek pertumbuhan perusahaan tersebut.

Berikut merupakan penelitian yang relevan yang berkaitan dengan corona virus dan kinerja saham.

\section{Tabel 1}

Telaah Penelitian Sebelumnya

\begin{tabular}{|c|c|c|c|c|}
\hline No & $\begin{array}{c}\text { Peneliti dan } \\
\text { Tahun }\end{array}$ & Judul & Variabel & Hasil Penelitian \\
\hline 1 & $\begin{array}{l}\text { Soureka \& } \\
\text { Muchlis, } 2007\end{array}$ & $\begin{array}{l}\text { Stock } \\
\text { Performance } \\
\text { Analysis } \\
\text { Before and } \\
\text { after Stock }\end{array}$ & $\begin{array}{l}\text { 1. Analisis teknikal } \\
\text { dengan indikator } \\
\text { closing price dan } \\
\text { stock trading } \\
\text { volume }\end{array}$ & $\begin{array}{l}\text { Analisis kinerja saham sebelum dan } \\
\text { sesudah stock split dengan teknikal } \\
\text { dinilai lebih baik karena closing price } \\
\text { dan stock trading volume menunjukkan } \\
\text { nilai perusahaan secara langsung }\end{array}$ \\
\hline
\end{tabular}




\begin{tabular}{|c|c|c|c|c|}
\hline & & $\begin{array}{l}\text { Split on Basic } \\
\text { Industry and } \\
\text { Chemical in } \\
\text { Indonesia }\end{array}$ & $\begin{array}{l}\text { 2. Analisis } \\
\text { fundamental } \\
\text { dengan indikator } \\
\text { Earning Per Share } \\
\text { (EPS) dan Price } \\
\text { Earning Ratio } \\
\text { (PER) }\end{array}$ & $\begin{array}{l}\text { berdasarkan daya beli investor. } \\
\text { Sedangkan analisis fundamental, EPS } \\
\text { dan DER tidak menciptakan perbedaan } \\
\text { yang signifikan, namun } \\
\text { EPS dan PER memiliki korelasi kuat } \\
\text { sebelum dan sesudah stock split. Investor } \\
\text { lebih menyukai analissi teknikal untuk } \\
\text { pengambilan keputusan investasi. }\end{array}$ \\
\hline 2 & Ayu et al., 2013 & $\begin{array}{l}\text { Analisis } \\
\text { Kinerja Saham } \\
\text { Sebelum Dan } \\
\text { Sesudah Stock } \\
\text { Split Pada } \\
\text { Perusahaan } \\
\text { Yang Terdaftar } \\
\text { Di Bursa Efek } \\
\text { Indonesia }\end{array}$ & $\begin{array}{l}\text { Kinerja saham dengan } \\
\text { dua indikator yaitu } \\
\text { sebelum dan sesudah } \\
\text { stock split }\end{array}$ & $\begin{array}{l}\text { Hasil pengujian dengan menggunakan } \\
\text { paired sample t-test menunjukkan bahwa } \\
\text { terdapat perbedaan return saham tetapi } \\
\text { tidak signifikan sebelum dan setelah } \\
\text { peristiwa pengumuman stock split. Ini } \\
\text { berarti bahwa pasar tidak bereaksi dan } \\
\text { tidak merespon peristiwa tersebut karena } \\
\text { dianggap tidak cukup membawa } \\
\text { informasi yang menguntungkan bagi } \\
\text { investor. Penurunan angka pertumbuhan } \\
\text { perekonomian dan penurunan tingkat } \\
\text { EPS atau laba per lembar saham } \\
\text { menyebabkan investor tidak tertarik } \\
\text { untuk berinvestasi. }\end{array}$ \\
\hline 3 & $\begin{array}{l}\text { Khan et al., } \\
2020\end{array}$ & $\begin{array}{l}\text { Novel } \\
\text { coronavirus, } \\
\text { poor } \\
\text { quarantine, and } \\
\text { the risk of } \\
\text { pandemic }\end{array}$ & $\begin{array}{l}\text { Coronavirus disease } \\
\text { (covid-19) }\end{array}$ & $\begin{array}{l}\text { Penyebaran virus corona merupakan hal } \\
\text { yang baru di dunia. Pemerintah di } \\
\text { seluruh dunia sedang berjuang untuk } \\
\text { menemukan cara untuk mencegah } \\
\text { penyebaran virus corona. Beberapa } \\
\text { negara termasuk Singapura, Australia, } \\
\text { Inggris, Jepang, dan AS melarang } \\
\text { pengunjung dari Cina, dan warga negara } \\
\text { mereka bepergian ke Cina. Selain itu } \\
\text { setiap warga Negara diharuskan } \\
\text { dikarantina selama } 14 \text { hari sebelum } \\
\text { memasuki negara asalnya. Namun, } \\
\text { situasinya semakin di luar kendali dan } \\
\text { risiko pandemi di seluruh dunia semakit } \\
\text { meningkat. }\end{array}$ \\
\hline 4 & Budiyanti, 2020 & $\begin{array}{l}\text { Dampak Virus } \\
\text { Corona } \\
\text { Terhadap } \\
\text { Sektor } \\
\text { Perdagangan } \\
\text { Dan Pariwisata } \\
\text { Indonesia }\end{array}$ & $\begin{array}{l}\text { Coronavirus disease } \\
\text { (covid-19) }\end{array}$ & 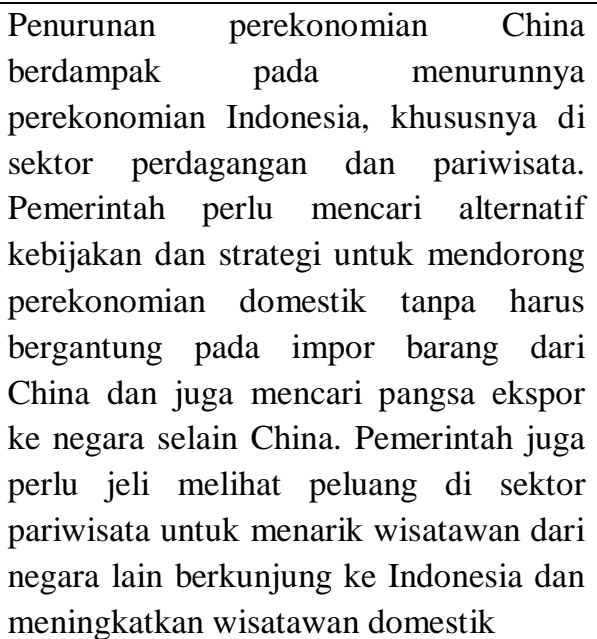 \\
\hline
\end{tabular}




\begin{tabular}{|c|c|c|c|c|}
\hline 5 & Evans, 2020 & $\begin{array}{l}\text { Socio- } \\
\text { economic } \\
\text { impacts of } \\
\text { novel } \\
\text { coronavirus: } \\
\text { The policy } \\
\text { solutions }\end{array}$ & $\begin{array}{l}\text { Coronavirus disease } \\
\text { (covid-19) }\end{array}$ & 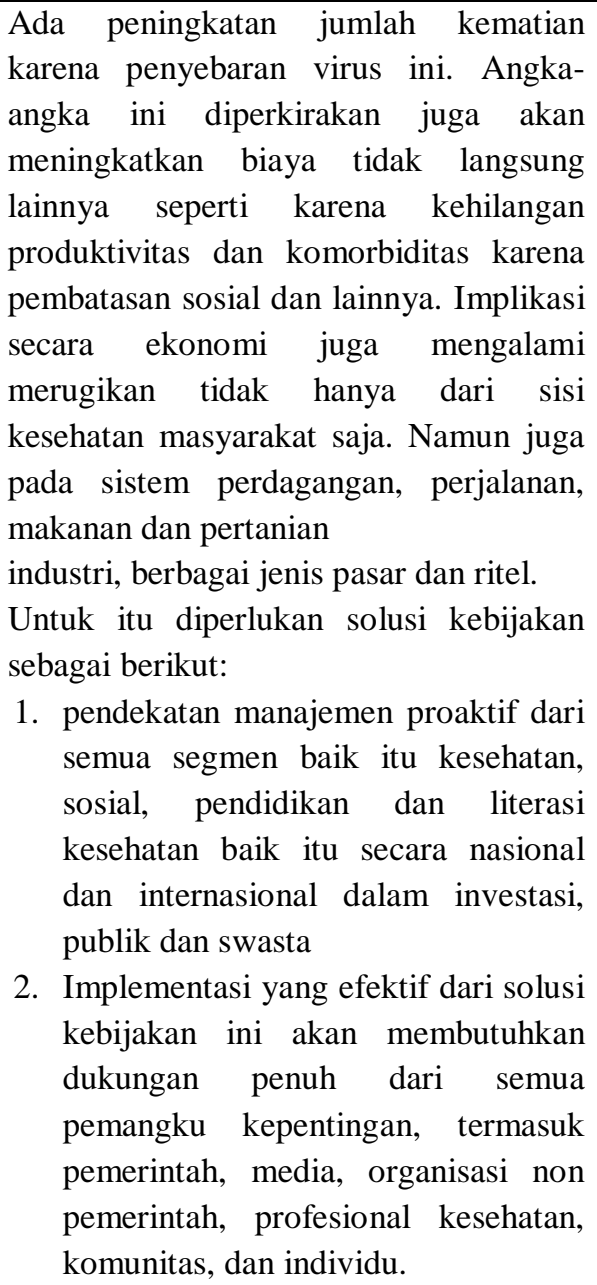 \\
\hline
\end{tabular}

Sumber : Data diolah, 2020

\subsection{Kerangka Pemikiran}

Berikut merupakan kerangka penelitian yang dilakukan berdasarkan permasalahan yang ada, adalah:

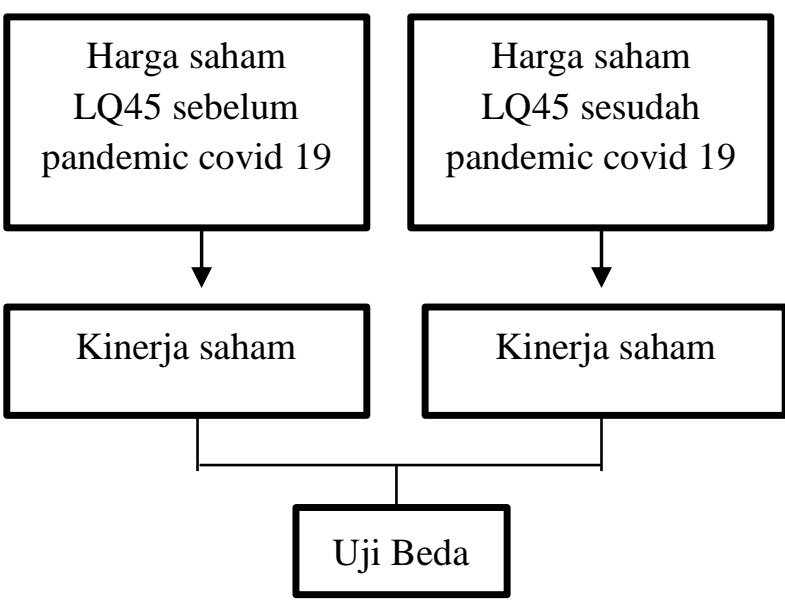

Gambar 1

Kerangka Pemikiran

\subsection{Hipotesis}

Berdasarkan atas hasil penelitian sebelumnya dan kerangka penelitian yang telah digambarkan, maka dirumuskan hipotesis sebagai berikut:

$\mathrm{H}_{\mathrm{a}}$ : Terdapat perbedaan kinerja saham LQ45 yang signifikan sebelum dan selama Pandemi Corona Virus pada perusahaan yang terdaftar di Bursa Efek Indonesia.

$\mathrm{H}_{0}$ : Tidak Terdapat perbedaan kinerja saham LQ45 yang signifikan sebelum dan selama Pandemik Corona Virus pada perusahaan yang terdaftar di Bursa Efek Indonesia.

\section{METODOLOGI PENELITIAN}

\subsection{Desain Penelitian}

Penelitian ini menggunakan pendekatan kuantitatif dengan menekankan pada pengujian hipotesis. Alat analisis yang digunakan adalah 
software IBM SPSS versi 20 untuk melihat deskripsi dan komparasi harga saham selama pandemi Covid 19 di Indonesia. Teknik dalam penelitian ini menggunakan penelitian kausal komparatif.

Studi kausal komparatif adalah studi yang berusaha mengamati alasan atau penyebab terjadinya suatu kejadian yang diteliti [12]. Penelitian ini menggunakan teknik penelitian komparatif karena dalam penelitian ini membandingkan harga saham sebelum dan sesudah adanya pandemic covid 19.

\subsection{Populasi dan Sampel}

Penelitian ini menggunakan sampling total atau sampling jenuh. Sampling jenuh adalah teknik penentuan sampel bila semua populasi digunakan sebagai semua sampel

Tabel 2

Sampel Penelitian

\begin{tabular}{|c|c|c|}
\hline No & $\begin{array}{c}\text { Kode } \\
\text { Emiten }\end{array}$ & Sektor \\
\hline 1 & ACES & $\begin{array}{c}\text { Trade, services and } \\
\text { investment }\end{array}$ \\
\hline 2 & ADRO & Mining \\
\hline 3 & AKRA & $\begin{array}{c}\text { Trade, services and } \\
\text { investment }\end{array}$ \\
\hline 4 & ANTM & Mining \\
\hline 5 & ASII & Miscellaneous Industry \\
\hline 6 & BBCA & Finance \\
\hline 7 & BBNI & Finance \\
\hline 8 & BBRI & Finance \\
\hline 9 & BBTN & Finance \\
\hline 10 & BMRI & Finance \\
\hline 11 & BRPT & $\begin{array}{c}\text { Basic industry and } \\
\text { chemicals }\end{array}$ \\
\hline 12 & BSDE & $\begin{array}{c}\text { Property, RE and Bld. } \\
\text { Construction }\end{array}$ \\
\hline 13 & BTPS & Finance \\
\hline 14 & CPIN & $\begin{array}{c}\text { Basic industry and } \\
\text { chemicals }\end{array}$ \\
\hline 15 & CTRA & $\begin{array}{c}\text { Property, RE and Bld. } \\
\text { Construction }\end{array}$ \\
\hline 16 & ERAA & $\begin{array}{c}\text { Trade, services and } \\
\text { investment }\end{array}$ \\
\hline
\end{tabular}

(Sugiyono, 2017). Sampel yang dipakai adalah populasi perusahaan yang listing dibursa efek dengan kategori indeks LQ45. Indeks LQ45 adalah indeks pasar saham di Bursa Efek Indonesia yang terdiri dari 45 perusahaan yang memenuhi kriteria tertentu, yaitu likuiditas tinggi, kapitalisasi pasar yang besar dan fundamental perusahaan yang baik [5].

Sampel dalam penelitian ini diambil menggunakan metode sampling total atau sampling jenuh. Sampling jenuh adalah teknik penentuan sampel bila semua populasi digunakan sebagai sampel [13]. Sampel yang digunakan adalah semua emiten yang masuk kategori indeks LQ45 yaitu sebanyak 45 emiten.

\begin{tabular}{|c|c|c|}
\hline 17 & EXCL & $\begin{array}{c}\text { Infras, utilities and } \\
\text { transportation }\end{array}$ \\
\hline 18 & GGRM & Consumer goods industry \\
\hline 19 & HMSP & Consumer goods industry \\
\hline 20 & ICBP & Consumer goods industry \\
\hline 21 & INCO & Mining \\
\hline 22 & INDF & Consumer goods industry \\
\hline 23 & INKP & $\begin{array}{c}\text { Basic industry and } \\
\text { chemicals }\end{array}$ \\
\hline 24 & INTP & $\begin{array}{c}\text { Basic industry and } \\
\text { chemicals }\end{array}$ \\
\hline 25 & ITMG & Mining \\
\hline 26 & JPFA & $\begin{array}{c}\text { Basic industry and } \\
\text { chemicals }\end{array}$ \\
\hline 27 & JSMR & $\begin{array}{c}\text { Infras, utilities and } \\
\text { transportation }\end{array}$ \\
\hline 28 & KLBF & Consumer goods industry \\
\hline 29 & LPPF & $\begin{array}{c}\text { Trade, services and } \\
\text { investment }\end{array}$ \\
\hline 30 & MNCN & $\begin{array}{c}\text { Trade, services and } \\
\text { investment }\end{array}$ \\
\hline 31 & PGAS & $\begin{array}{c}\text { Infras, utilities and } \\
\text { transportation }\end{array}$ \\
\hline 32 & PTBA & mining \\
\hline 33 & PTPP & $\begin{array}{c}\text { Property, RE and Bld. } \\
\text { Construction }\end{array}$ \\
\hline 34 & PWON & $\begin{array}{c}\text { Property, RE and Bld. } \\
\text { Construction }\end{array}$ \\
\hline
\end{tabular}




\begin{tabular}{|c|c|c|}
\hline 35 & SCMA & $\begin{array}{c}\text { Trade, services and } \\
\text { investment }\end{array}$ \\
\hline 36 & SMGR & $\begin{array}{c}\text { Basic industry and } \\
\text { chemicals }\end{array}$ \\
\hline 37 & SRIL & Miscellaneous Industry \\
\hline 38 & TBIG & $\begin{array}{c}\text { Infras, utilities and } \\
\text { transportation }\end{array}$ \\
\hline 39 & TKIM & $\begin{array}{c}\text { Basic industry and } \\
\text { chemicals }\end{array}$ \\
\hline 40 & TLKM & $\begin{array}{c}\text { Infras, utilities and } \\
\text { transportation }\end{array}$ \\
\hline
\end{tabular}

\subsection{Teknik Pengambilan Data}

Sumber pengumpulan data dalam penelitian ini menggunakan data sekunder. Data sekunder dalam penelitian ini berupa harga saham perbulan sebelum dan setelah adanya pandemic covid 19. Analisis dilakukan mulai bulan September 2019-April 2020 selama 8 bulan yang tersaji di bursa efek Indonesia. Sampel sebanyak 45 emiten dengan indeks LQ45 dapat dilihat pada website [5].

\subsection{Definisi Operasional Variabel}

Indeks LQ45 adalah indeks saham unggulan yang ada di bursa saham Indonesia. Indeks ini terdiri dari 45 saham emiten yang ada di Indonesia dengan kategori perusahaan dengan reputasi yang baik.

Berdasarkan pada indeks LQ45 tersebut, penelitian ini mengukur harga saham sebagai variabel. Harga saham merupakan salah satu bentuk efek atau surat berharga yang diperdagangkan di pasar modal (bursa efek). Harga saham yang dimaksud dalam penelitian ini adalah harga saham penutupan akhir (closing price) tiap perusahaan yang diperoleh dari harga saham pada penutupan perhari yang kemudian dihitung rata-rata perbulannya. Periode waktu pada penelitian ini yaitu bulan Agustus 2019 - Januari 2020 sebagai indikator sebelum adanya pandemik covid 19 di Indonesia. Sedangkan bulan Februari - Juni 2020 sebagai indokator setelah adanya pandemik covid 19 di Indonesia.

\begin{tabular}{|c|c|c|}
\hline 41 & TOWR & $\begin{array}{c}\text { Infras, utilities and } \\
\text { transportation }\end{array}$ \\
\hline 42 & UNTR & $\begin{array}{c}\text { Trade, services and } \\
\text { investment }\end{array}$ \\
\hline 43 & UNVR & Consumer goods industry \\
\hline 44 & WIKA & $\begin{array}{c}\text { Property, RE and Bld. } \\
\text { Construction }\end{array}$ \\
\hline 45 & WSKT & $\begin{array}{c}\text { Property, RE and Bld. } \\
\text { Construction }\end{array}$ \\
\hline
\end{tabular}

Sumber: BEI, 2020

\subsection{Teknik Analisis Data}

Teknik analisis yang digunakan dalam penelitian ini adalah analisis statistik deskriptif, uji validitas dan reabilitas, uji normalitas dan uji t.

Uji validitas dilakukan dengan menggunakan Pearson Product Moment sedangkan uji reliabilitas yang digunakan adalah dengan menggunakan Chronbach's Alpha. Analisis selanjutnya adalah uji normalitas yang bertujuan untuk mengetahui penyebaran data berdistribusi normal atau tidak. Pengujian normalitas juga dapat dilakukan dengan uji kolmogorov smirnov. Kriteria yang digunakan adalah jika nilai signifikansi atau Asymp. Sig. > 0,05 maka dapat diartikan data berdistribusi normal dan begitu juga sebaliknya, jika nilai signifikansi atau Asymp. Sig. < 0,05 maka data tidak berdistribusi normal [13].

Setelah dilakukan uji normalitas, analisis selanjutnya adalah uji hipotesis. Uji hipotesis digunakan untuk menentukan jawaban sementara pada penelitian sesuai atau tidak dengan hasil penelitian, maka data terlebih dahulu dianalisa menggunakan uji t. Pengujian dilakukan dengan menggunakan metode Paired Sample t-Test untuk menguji sampel yang berpasangan. Paired Sample adalah sebuah sampel yang sama namun mengalami dua perlakuan atau pengukuran yang berbeda [14].Teknik Paired Sample tTest merupakan metode perhitungan statistik untuk mengetahui perbedaan yang signifikan 
pada harga saham sebelum dan sesudah pandemic covid 19 di Indonesia.

Pedoman pengambilan keputusan dalam uji paired sample t-test berdasarkan nilai signifikansi (Sig.) hasil output SPSS adalah sebagai berikut: [14]

\section{HASIL DAN PEMBAHASAN}

\subsection{Hasil Penelitian}

\section{Uji validitas}

Berdasarkan uji validitas dengan product moment, berikut merupakan hasil analisis yang dilakukan:
1. jika nilai Sig. (2-tailed) $<0,05$, makan Ho dan Ha diterima

2. sebaliknya, jika nilai Sig. (2-tailed) > 0,05, maka Ho diterima dan Ha ditolak

Tabel 3

Hasil Pengujian Validitas - Product Moment

\begin{tabular}{|c|c|c|c|}
\hline $\begin{array}{c}\text { Bulan } \\
\text { ke }\end{array}$ & $\begin{array}{c}\text { Nama } \\
\text { Bulan }\end{array}$ & T-Hitung & Keterangan \\
\hline 1 & Agustus & $.975^{* *}$ & Valid \\
\hline 2 & September & $.960^{* *}$ & Valid \\
\hline 3 & Oktober & $.973^{* *}$ & Valid \\
\hline 4 & November & .779 & Valid \\
\hline 5 & Desember & $.975^{* *}$ & Valid \\
\hline 6 & Januari & $.962^{* *}$ & Valid \\
\hline 7 & Februari & $.959^{* *}$ & Valid \\
\hline 8 & Maret & $.709^{* *}$ & Valid \\
\hline 9 & April & $.970^{* *}$ & Valid \\
\hline 10 & Mei & $.965^{* *}$ & Valid \\
\hline 11 & Juni & $.965^{* *}$ & Valid \\
\hline
\end{tabular}

Sumber : Data primer yang diolah, 2020

Pengujian ini menggunakan uji validitas dengan product moment. Jumlah waktu yang dianalisis adalah sebelum dan selama pandemic covid-19 sebanyak 11 bulan (Agustus 2019-Juni 2020) dengan tingkat signifikasi sebesar $5 \%$, sehingga nilai t-tabel 0,602 , artinya jika nilai yang pada t-hitung lebih besar dari nilai t-tabel, butir pertanyaan pada kuesioner adalah valid.
Berdasarkan hasil analisis, menunjukkan bahwa waktu analisis yangdipakai dalam penelitian telah valid dan/atau memiliki ukuran yang tepat terhadap variabel yang digunakan.

\section{Uji Reliabilitas}

Hasil pengujian reliabilitas untuk masing-masing variabel yang diringkas pada tabel berikut ini : 
Tabel 7

Hasil Pengujian Reliabilitas

\begin{tabular}{|l|c|c|c|c|}
\hline Variabel & $\begin{array}{c}\text { Indikator } \\
\text { ke }\end{array}$ & Indikator & $\begin{array}{c}\text { Cronbach's } \\
\text { Alpha }\end{array}$ & Keterangan \\
\hline & 1 & Agustus & 0,693 & Valid \\
\cline { 2 - 5 } & 2 & September & 0,702 & Valid \\
\cline { 2 - 5 } & 3 & Oktober & 0,700 & Valid \\
\cline { 2 - 5 } $\begin{array}{l}\text { Sebelum } \\
\text { Pandemi }\end{array}$ & 4 & November & 0,967 & Valid \\
\cline { 2 - 5 } & 5 & Desember & 0,701 & Valid \\
\cline { 2 - 5 } & 6 & Januari & 0,707 & Valid \\
\hline \multirow{3}{*}{$\begin{array}{l}\text { Selama } \\
\text { Pandemi }\end{array}$} & 7 & Februari & 0,711 & Valid \\
\cline { 2 - 5 } & 9 & Maret & 0,718 & Valid \\
\cline { 2 - 5 } & 10 & April & 0,714 & Valid \\
\cline { 2 - 5 } & 11 & Mei & 0,712 & Valid \\
\hline
\end{tabular}

Sumber : Data primer yang diolah, 2020

Berdasarkan Tabel 3 diatas hasil pengujian reliabilitas dari masing-masing pengukuran variabel diperoleh bahwa semua variabel mempunyai koefisien Alpha yang lebih besar dari 0,60 sehingga dapat dikatakan

Pengujian asumsi normalitas dilakukan dengan menggunakan Uji Wilcoxon Signed semua konsep pengukur variabel-variabel yang digunakan dalam penelitian ini adalah reliabel.

\section{Uji Normalitas}

Ranks Test. Hasil pengujian normalitas dapat dilihat pada Tabel 8 berikut ini :

\section{Tabel 4}

Uji Normalitas

\begin{tabular}{|l|c|c|}
\hline \multicolumn{3}{|c|}{ Wilcoxon Signed Ranks Test } \\
\hline statistic & $\mathrm{Z}$ & Asymp. Sig. (2-tailed) \\
\hline selamacovid19 - sebelumcovid19 & $-5.774^{\mathrm{b}}$ & 0,70 \\
\hline
\end{tabular}

Sumber : Data primer yang diolah, 2020

Berdasarkan tabel 4 di atas, hasil pengujian tersebut menunjukkan nilai signifkansi Wilcoxon Signed Ranks Test sebesar 0,070 yang lebih besar dari 0,05. Hal ini membuktikan bahwa variabel yang diteliti distribusi normal.

\section{Uji Hipotesis}

Tabel 5

Hasil Uji Paired T-Test

\begin{tabular}{|l|l|l|l|l|}
\hline Variabel & Rata-rata & t-hitung & Signifikansi & Keterangan \\
\hline $\begin{array}{l}\text { Sebelum pandemic- } \\
\text { Selama pandemi }\end{array}$ & $\mathbf{2 . 1 3 7 , 5 7}$ & 3,009 & 0,004 & signifikan \\
\hline
\end{tabular}

Sumber : Data Primer yang diolah, 2020

Hasil perhitungan diperoleh nilai signifikansi 0,004 yang artinya signifikansi lebih kecil dari 0,05 dan dapat diambil kesimpulan bahwa terdapat perbedaan yang signifikan sebelum dan selama Covid-19 di Indonesia pada saham
LQ45 di Bursa efek Indonesia. Hal ini juga dibuktikan dengan nilai rata-rata sebelum selama pandemic yaitu 2.137,57. Nilai t hitung dari hasil analisis olah data adalah sebesar 3,009 dengan sig 0.004, maka dapat 
disimpulkan bahwa $\mathrm{H}_{\mathrm{a}}$ diterima dan $\mathrm{H}_{\mathrm{o}}$ ditolak, artinya terdapat perbedaan kinerja saham LQ45 yang signifikan sebelum dan selama Pandemi Corona Virus pada perusahaan yang terdaftar di Bursa Efek Indonesia. Demikian dapat dinyatakan bahwa Pandemi covid-19 mempengaruhi kinerja saham LQ45 di Bursa Efek Indonesia.

\subsection{Pembahasan}

Hasil penelitian menunjukkan bahwa terdapat perbedaan kinerja saham LQ45 yang signifikan sebelum dan selama Pandemi Corona Virus pada perusahaan yang terdaftar di Bursa Efek Indonesia. Kinerja saham LQ45 pada bursa saham Indonesia mengalami penurunan selama masa pandemic yang terjadi di Indonesia. Situasi ini menyebabkan banyak perusahaan mengalami kerugian.

Penelitian yang berkaitan dengan analisis saham selama pandemi covid-19 masih sangat jarang dilakukan mengingat situasi ini baru terjadi di dunia dan masuk ke Indonesia sekitar permulaan Desember 2019 hingga sekarang. Tentunya penelitian yang berkaitan dengan penurunan saham LQ45 selama pandemi belum bisa dibandingkan dengan penelitian yang serupa. Namun berdasarkan penelitian terdahulu yang membahas tentang perubahan saham sebelum dan setelah karena kondisi tertentu, membuktikan bahwa saham dengan perlakuan khusus (stock split) tidak merubah kinerja saham itu sendiri. Bahkan investor lebih menyukai analisis teknikal dalam pengambilan keputusan investasi. Secara umum, pasar tidak merespon sebagai informasi tambahan yang menguntungkan investor sehingga belum memberikan good news kepada investor (Naomi Stephanie Soureka dan Tanti Irawati Muchlis, 2013; dan I Gusti Ayu Winda Swari dan I Gusti Bagus Wiksuana, 2015).

Sebelum pandemi terjadi di Indonesia, hasil penelitian menunjukkan kinerja yang baik pada perekonomian Indonesia. Hasil ini juga menggambarkan bahwa kinerja saham pada bursa efek Indonesia tidak mengalami lonjakan penurunan yang drastis, namun setelah masuk pandemic virus covid-19 telah membuat keuangan Indonesia mengalami resesi dan penurunan kinerja keuangan pada hampir semua saham yang ada di bursa efek Indonesia termasuk saham LQ45.

\section{KESIMPULAN}

Berdasarkan pada hasil penelitian disimpulkan bahwa terdapat perbedaan kinerja saham sebelum dan selama pandemic covid-19 pada saham LQ45 yang menggambarkan penurunan kinerja selama masa pandemic yang melanda Indonesia. Hal ini terlihat dengan performa saham yang masuk dalam kategori LQ45 selama pandemi memiliki Performa Saham yang menurun karena selama pandemi ini semua perekonomian dunia mengalami penurunan sehingga berpengaruh terhdap kinerja saham LQ45, walaupun saham ini mempunyai nilai kapitalisasi pasar yang tinggi. Jika dikaitkan dengan tingkat risikonya, maka saham LQ45 memiliki tingkat risiko lebih kecil dibandingkan dengan saham lainnya karena saham gabungan dari perusahaan yang memiliki likuiditas yang tinggi sehingga perputarannya lebih cepat dari saham biasa.

\section{SARAN}

Berdasarkan pada kesimpulan yang dijabarkan, beberapa saran yang dapat disampaikan bahwa diperlukan analisis yang lebih luas lagi berkaitan dengan kinerja saham selama pandemic untuk bisa mengidentifikasi penurunan saham yang lebih spesifik seperti dengan analisis tekhnikal. Selanjutnya ada regulasi untuk menarik minat investor dengan tetap berinvestasi dan situasi pandemic segera berakhir sehingga pembatasan kegiatan tidak ada lagi. Hal ini membuat kegiatan bisnis dapat berjalan seperti semula tanpa adanya ketakutan pada virus covid-19 yang mewabah. 
VIII. DAFTAR PUSTAKA

[1] N. S. P. Suni, "Kesiapsiagaan Indonesia Menghadapi Potensi Penyebaran Corona," Pus. Penelit. Badan Keahlian $D P R ~ R I$, vol. XII, no. 3, pp. 14-18, 2020, [Online]. Available: https://berkas.dpr.go.id/puslit/files/info _singkat/Info Singkat-XII-3-I-P3DIFebruari-2020-1957.pdf.

[2] Kompas.com, "1,7 Juta Orang di Dunia Terinfeksi Covid-19, Ini Daftar 5 Negara dengan Kasus Corona Terbanyak," 2019.

[3] H. Kusuma, "Virus Corona Gerogoti Ekonomi RI, Seperti Apa Dampaknya?," detikFinance, 2019.

[4] R. Analytics, "Harga Saham LQ-45 Turun Drastis Sejak Awal Tahun," Databoks, 2020 https://databoks.katadata.co.id/datapubl ish/2020/03/13/harga-saham-lq-45turun-drastis-sejak-awal-tahun.

[5] Idx, "Indeks Saham," idx.co.id, 2020. https://www.idx.co.id/Produk/Indeks/ (accessed Apr. 14, 2020).

[6] C. D. Polakitan, "Analisis Komparasi Resiko Saham.... (Polakitan) 61," J. Ris. Bisnis dan Manaj., vol. 3, pp. 6172, 2015.

[7] N. S. Soureka and T. I. Muchlis, "Stock Performance Analysis Before and after Stock Split on Basic Industry and Chemical in Indonesia," pp. 175-179,
2013.

[8] I. G. Ayu, W. Swari, and I. G. B. Wiksuana, "SPLIT PADA PERUSAHAAN YANG TERDAFTAR DI BURSA EFEK INDONESIA Fakultas Ekonomi dan Bisnis Universitas Udayana ( Unud ), Bali , Indonesia berinvestasi atau tidak pada suatu sekuritas . Kinerja saham yang positif dapat yang dapat memuaskan investor . Kinerja," pp. 275-289, 2015.

[9] S. Khan, R. Siddique, A. Ali, M. Xue, and G. Nabi, "Novel coronavirus, poor quarantine, and the risk of pandemic," J. Hosp. Infect., vol. 104, no. 4, pp. 449-450, 2020, doi: 10.1016/j.jhin.2020.02.002.

[10] E. Budiyanti, "Dampak Virus Corona Terhadap Sektor Perdagangan Dan," vol. 2015, 2020.

[11] O. Evans, "B i z econs Q uarterly," no. March, 2020.

[12] J. Noor, Metodologi Penelitian: Skripsi, Tesis, Disertasi dan Karya Ilmiah. Kencana Prenada Media Group, 2011.

[13] I. Ghozali, Aplikasi Analisis Multivariate dengan Program IBM SPSS 25 (edisikesembilan). Badan Penerbit Universitas Diponegoro, 2018.

[14] S. Santoso, Panduan Lengkap SPSS Versi 23. Elex Media Komputindo, 2016. 